\title{
Influence of the dynamics of seed sprouting on the differentiation of morphological features of tomato seedlings
}

\author{
EWA ROŻEK, JAN DYDUCH \\ Department of Horticulture and Medicinal Plants, Agricultural Academy in Lublin, \\ 58 Leszczyńskiego Street, 20-068 Lublin
}

(Received: July 24, 1998)

\begin{abstract}
The aim of the present study was to determine the relation between the quality of seed germination and morphological differentiation of seedlings of the studied tomato cultivars. The seeds of very early tomato cultivars (Beta, Betalux, Promyk) compared to the semi-early New Yorker cultivar treated as control were subjected to evaluation. It was found out that their germination rate significantly affected the quantity of obtained seedlings. The seedlings grown from seeds that germinated after 5 days were significantly higher than those that germinated after 7 or 10 days. They also had higher number of leaves, larger diameter of root collar and higher fresh mass.
\end{abstract}

\section{INTRODUCTION}

Tomato yielding in field cultivation depends to a high degree on the weather conditions that in our country are not always favourable for this species. Hence, early cultivars are very important in tomato production as they are more reliable in periods with unfavourable weather and are able to set fruits in lower temperatures. Cultivars of the Beta and Promyk type fulfill these requirements. However, studies by Dąbrowska et al. (1987) proved that the seeds of Beta type are characterized by cover vigour when compared to the seeds of New Yorker cultivar used as a control. Differentiation of the seed material of these cultivars resulted from varied stage of seed development, and high percentage of dead seeds (up to $30 \%$ ), light seeds (about $20 \%$ ) and low resistance of these seeds to pathogenic fungi. Later studies by Dąbrowska and Pyzik (1988) confirmed high percentage of the seeds from the light fraction (11 to $33 \%$ ) and 4 to 6 times higher content of moulded seeds in this fraction. Uneven sprouting and high differentiation in the quality of seedling is a well known problem with the Beta type seeds. Dąbrowska et al. (1987) advised to increase the sowing rate by $100 \%$ in the case of the latter seeds. 
The aim of the present studies was to determine relations between the quality of sprouting and morphological differentiation of seedlings of the studied tomato cultivars.

\section{MATERIAL AND METHODS}

The present studies were carried out in the period 1992-1994 in the Institute of Horticulture and Medicinal Plants of the Agricultural Academy in Lublin and in the greenhouse of the Experimental Farm of the Agricultural Academy in Lublin.

Seeds of three very early tomato cultivars (Beta, Betalux, and Promyk) were subjected to evaluation in comparison to semi-early New Yorker cultivar that was treated as a standard.

Dynamics of sprouting was studied in the laboratory environment (control; in temperature of $26-28^{\circ} \mathrm{C}$ ) and in the greenhouse. Observations were carried out on the same date. First count of the newly germinated seeds was conducted after 3 days from sowing, and next ones after 5, 7, 10, 12, and 14 days. Energy of seed germination was evaluated after 5 days, germination capacity after 14 days.

The second part of the experiment covered the studies on the germination dynamics of the tomato seed in the greenhouse environment. The seeds were sown in the first week of April on the Petri dishes, 200 seeds on one plate, in 4 replications for each cultivar in all the study years. They were then placed on benches in the greenhouse in temperature of $20-28{ }^{\circ} \mathrm{C}$ during the day and $14-20{ }^{\circ} \mathrm{C}$ at night.

In the course of sprouting (after 3, 5, 7, and 10 days from sowing), after the radicule had appeared, the seeds were transferred from the plates to pots and placed in rows $1 \mathrm{~cm}$ deep at $5 \times 5 \mathrm{~cm}$ spacing. Then they were covered with sand and watered. After 12 days from sowing, very few seeds were germinating, and for that reason they were not qualified for further observations.

The seedlings (after 24 days from sowing) obtained were then subjected to qualitative evaluation. Biometric measurements of 15 to 20 seedlings from each germination date were carried out; the mass of one seedling, its height, diameter of the radicule collar, and number of leaves were determined.

The study results were statistically elaborated by means of variance analysis according to cross-classification for non-orthogonal data. Statistical inference was carried out on the basis of multiple Tukey's test $(\alpha=0,05)$.

\section{RESULTS}

\section{Dynamics of seed sprouting}

In all the study years the seeds of the studied cultivars, except cv. Beta, both in the thermostat and in the greenhouse, sprouted to a markedly higher level (Fig. 1) than the required minimum germination capacity for the tomato seed $(80 \%$ for the $1 \mathrm{st}$ class and $70 \%$ for the 2 nd class) according to the Polish standard BN-85/116-01. Seeds of most tomato cultivars germinated better in laboratory conditions than in the greenhouse. Seeds of the cultivar Promyk were an exception in 1992 and 1994, as they germinated almost as quickly in greenhouse as in the thermostat. 

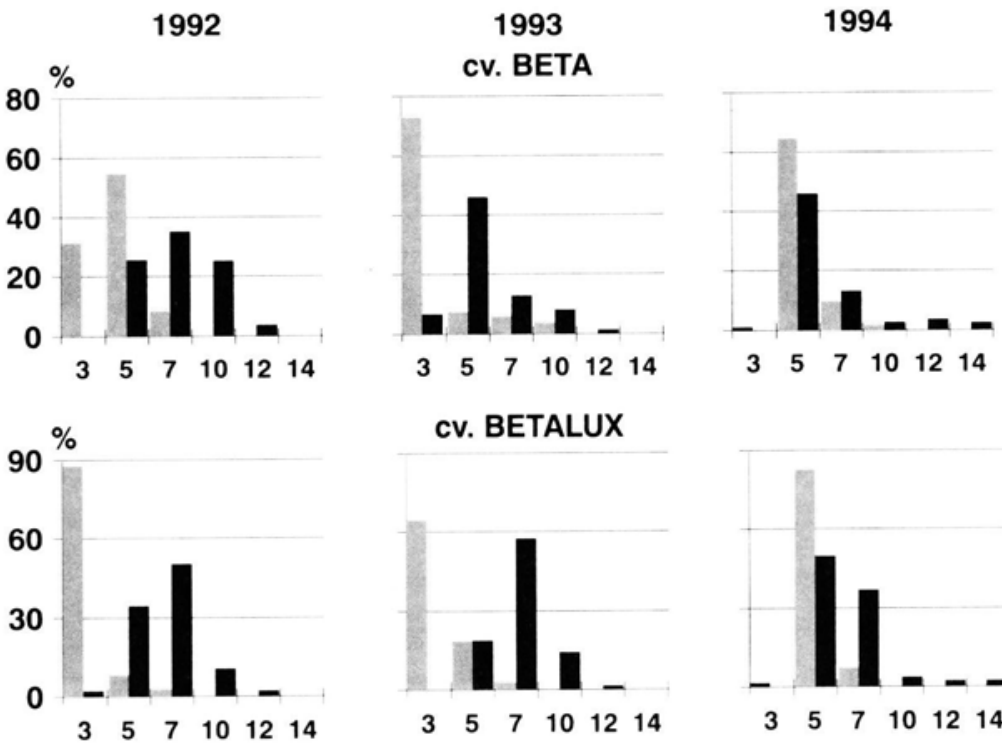

cv. BETALUX
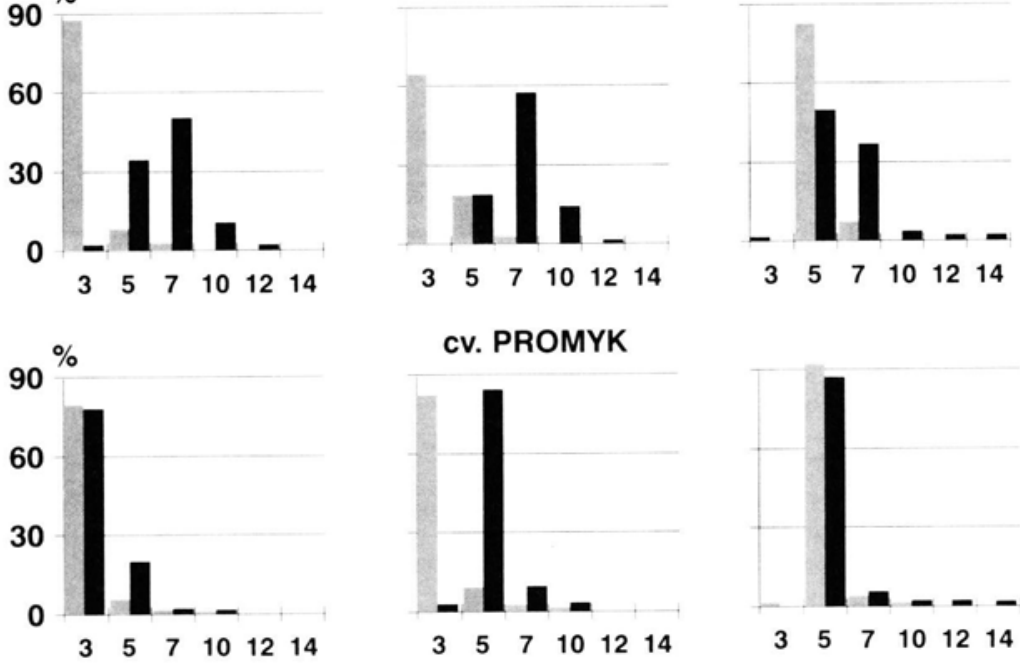

cv. PROMYK
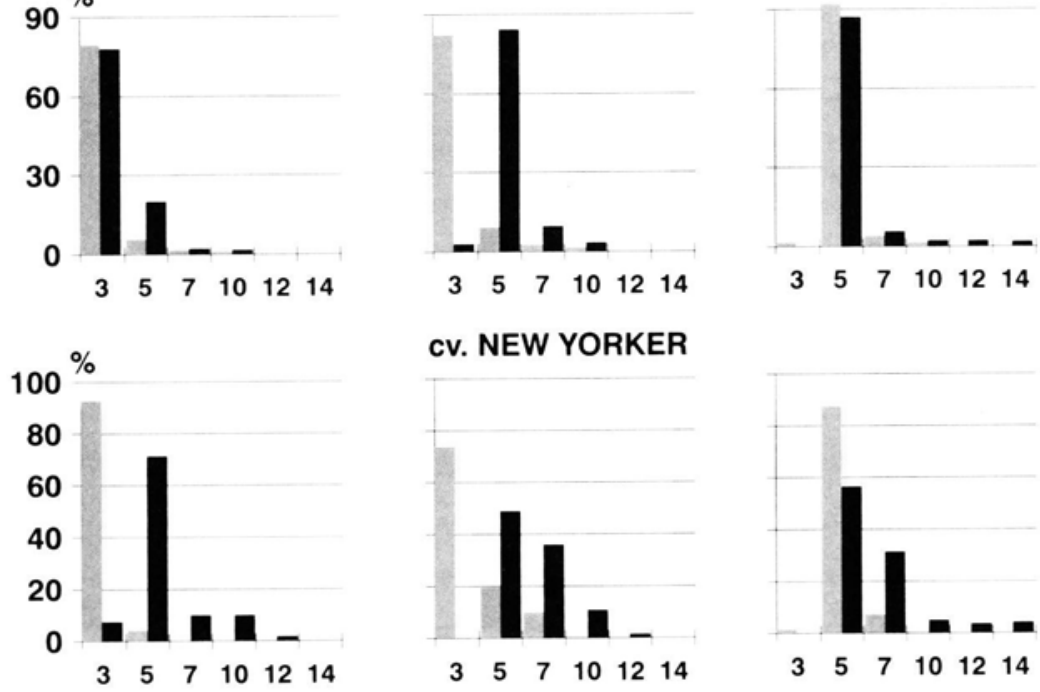

\section{cv. NEW YORKER}
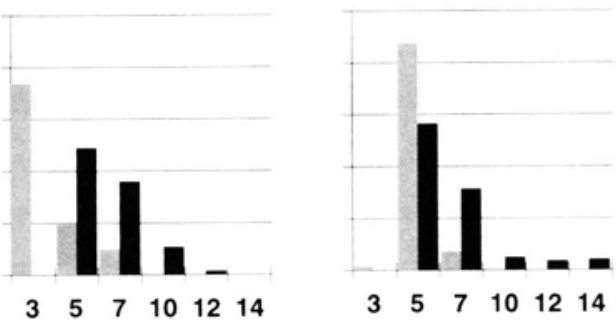

Thermostat

areenhouse

$3,5,7 \ldots-$ days from sowing to seed germination

Fig.1. Germination dynamics for the 4 tomato cultivars studied. 


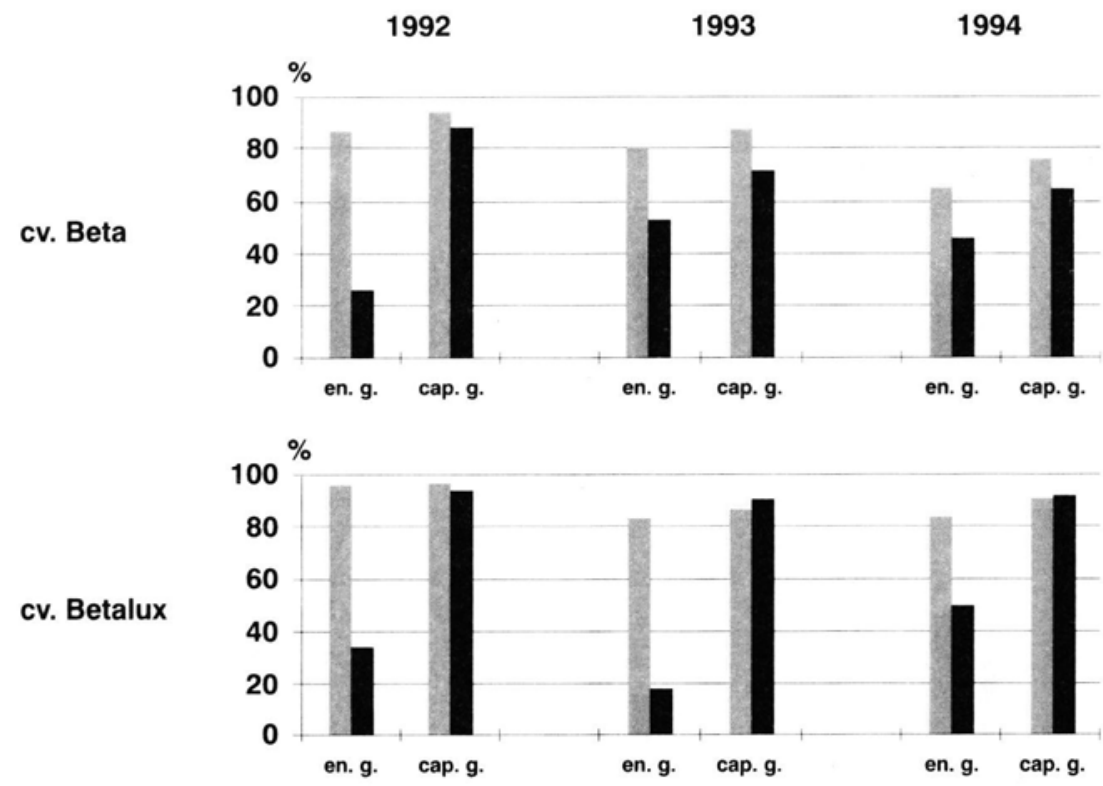

cv. Promyk

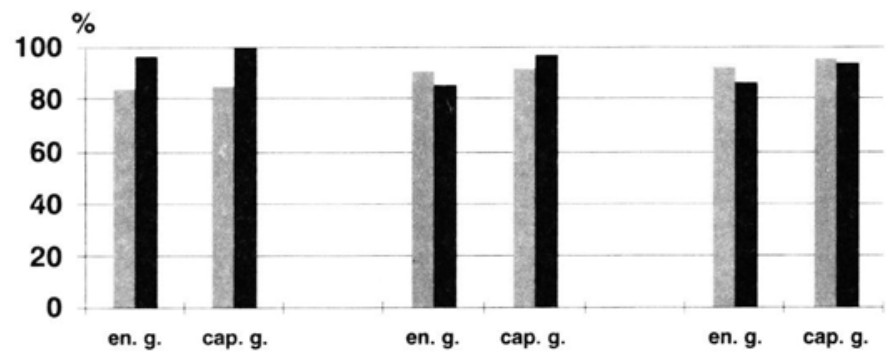

cv. New Yorker

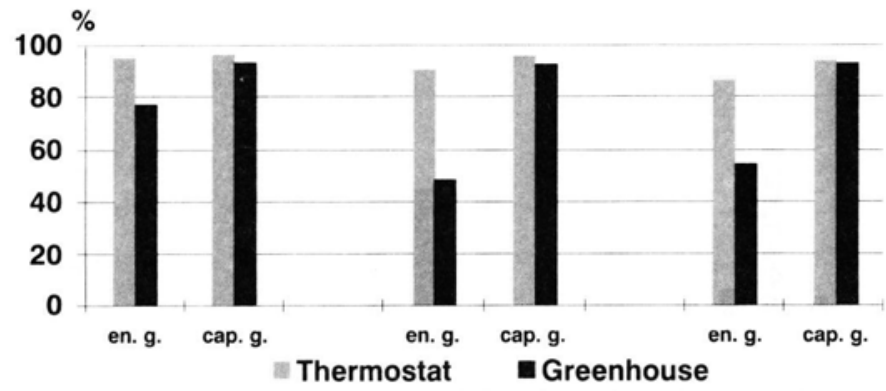

en. g. - energy of germination

en. cap. - capacity of germination

Fig. 2. Energy and germination capacity for the 4 tomato cultivars studied in the laboratory and greenhouse conditions (\%). 


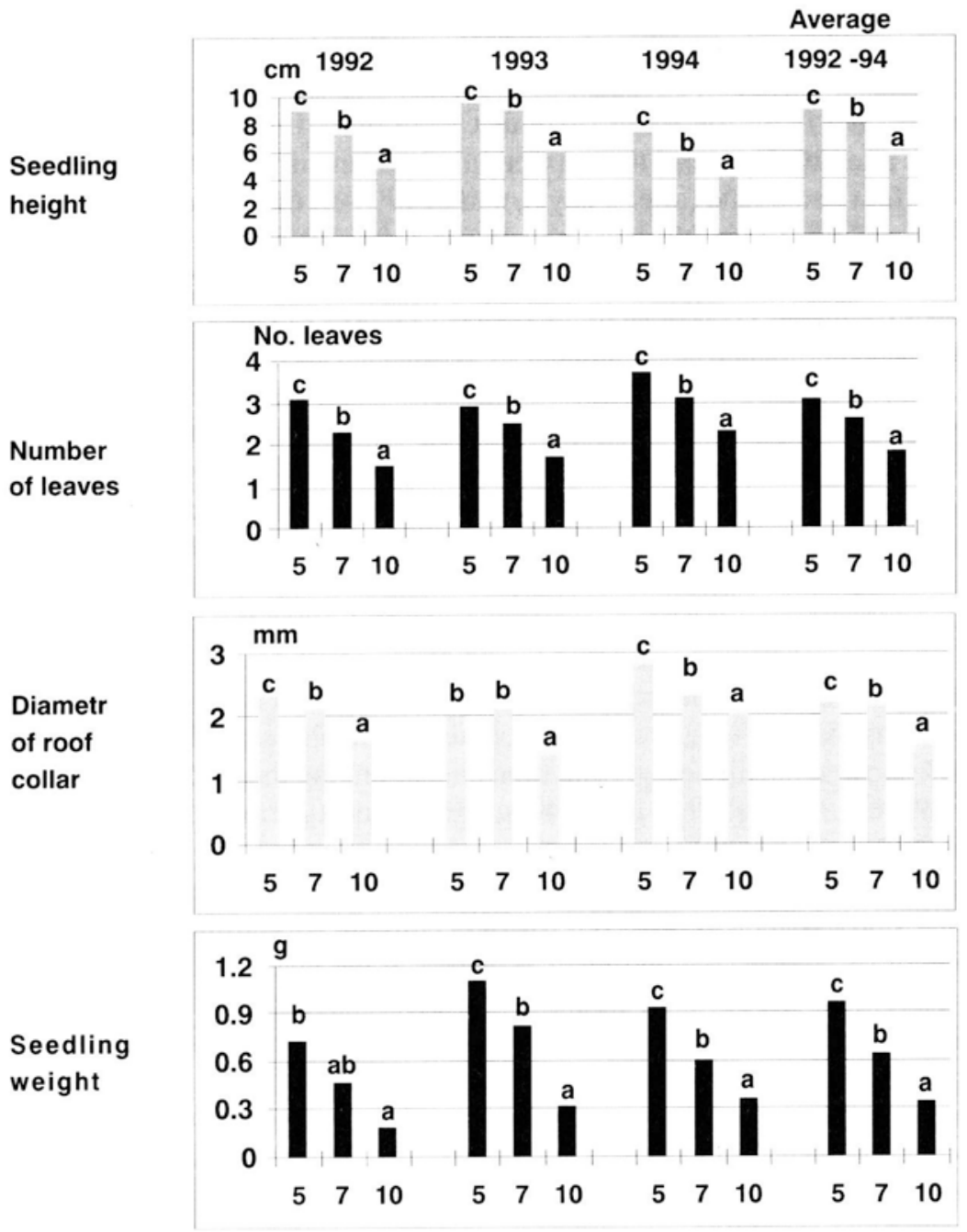

$5,7,10$ - number of days from seed sowing to germination

Fig. 3. Properties of seedlings grown from seeds of various germination dynamics (averages for 4 cultivars) 
In 1992 in the laboratory conditions the number of germinated seeds after 3 days was from $31 \%$ (cv. Beta) to $93 \%$ (cv. New Yorker), and in 1993 it was from 65\% (cv. Betalux) to $82 \%$ (cv. Promyk); whereas in 1994 only a small number of germinated seeds was observed after 3 days - about $1 \%$. In 1994 the highest number of germinated seeds was observed on the second counting date (after 5 days); then from $65 \%$ (cv. Beta) to $92 \%$ (cv. Promyk) of seeds germinated. The seeds of all the studied cultivars and in all the study years that were placed in the thermostat finished germination after 10 days, and the maximum of germination took place in 1992 and 1993 on the first count date (after 3 days), and in 1994 on the second count date (after 5 days). On the third (after 7 days) and fourth (after 10 days) count dates a small number of germinated seeds ranging from 0,0 to $10 \%$ was observed.

In the greenhouse conditions in the period 1992 to 1993 after 3 days from the beginning of the experiment a small number of germinated seeds $(0,9$ to $7,6 \%)$ was observed for all the cultivars except cv. Promyk, that germinated in 77\% in 1992. In 1994 in the greenhouse conditions no seeds germinating after 3 days were found. In all the study years the highest number of germinated seeds was observed on the 2 nd (after 5 days) and 3rd (after 7 days) day of count. In 1992 and 1993 no seeds germinating after 14 days were found, and in 1994 the seeds germinating on that count date were 1 to $3 \%$.

\section{Energy and capacity of germination}

In the laboratory conditions in years 1992 and 1993 the highest energy and capacity of germination was exhibited by the seeds of cv. New Yorker, and in 1994 by cv. Promyk (Fig. 2). In the case of these two cultivars seed germination capacity and energy was over $90 \%$. In greenhouse conditions in all years of the study seeds of cv. Promyk showed the highest germination energy among the studied cultivars ( $97 \%$ in $1992,86 \%$ in 1993 , and $86 \%$ in 1994), and the highest germination capacity (99\%, $97 \%$, and $94 \%$ respectively).

The lowest germination capacity and energy in the greenhouse conditions in all years of the study years was observed for Beta cultivar. Its germination capacity was at the level of $64-88 \%$, and germination energy at the level of $25-52 \%$. In the laboratory conditions the seeds of Beta cultivar germinated considerably better, especially in the years 1992 and 1993, showing germination capacity ranging from $88-94,0 \%$, and germination energy ranging from $80-86 \%$. In all the study years the seeds of Betalux cultivar were characterized by very low germination energy in the greenhouse $(19-50 \%)$. These seeds germinated much better in the thermostat where their germination energy ranged from 83 to $95 \%$.

\section{Characteristic of seedlings}

The results obtained during this three-year study proved that seed germination rate significantly influenced the quality of seedlings obtained from them. On the average seedlings obtained in the period 1992-1994 from seeds that germinated after 5 days were significantly higher than those obtained from the seeds that germinated after 7 and 10 days (Fig.3). They also had a significantly higher number of leaves, diameter of root collar and vegetation ma's. Analysis one year results it was found out that significant differences in all the studied features appeared between the seedlings from seeds that germinated after 5 and 10 days in all the study years. No significant differences were noticed only in 1993 between the seedlings obtained from seeds that 
germinated after 5 and 7 days when the feature studied was the diameter of root collar, and in 1992 between the seedlings obtained from the seeds that germinated after 5 and 7 days, and after 7 and 10 days, when the studied features was seed mass.

Biometric measurements of seedlings in the period 1992-1994 proved that on the average the seedlings of the Promyk cultivar were the highest (Table 1) and were characterized by the biggest diameter of the root collar (Table 3). In this respect they were significantly different from the remaining cultivars. No significant differences appeared between the seedlings of the Beta and Betalux cultivars in respect to the features mentioned above.

Seedlings of the Promyk cultivar were also characterized, compared to other cultivars, by a significantly higher number of leaves (Table 2). Considering the average number of leaves in seedlings, Betalux and New Yorker cultivars differed significantly. The seedlings of New Yorker and Promyk (Table 4) had, on the average, the highest vegetable mass. A significantly lower seedling mass was noted in the Beta and Betalux cultivars.

Table 1

Diameter of the radicule collar of seedlings grown from the seeds germinating after 5, 7, and 10 days (in cm), average from the period 1992-1994.

\begin{tabular}{|l|c|c|c|c|}
\hline \multirow{2}{*}{ Cultivar } & \multicolumn{4}{|c|}{ Number of days from seed sowing to germination } \\
\cline { 2 - 5 } & $\mathbf{5}$ & $\mathbf{7}$ & $\mathbf{1 0}$ & Average \\
\hline Beta & 7,0 & 6,5 & 5,4 & $6,3 \mathrm{a}$ \\
\hline Betalux & 6,3 & 6,9 & 4,8 & $6,1 \mathrm{a}$ \\
\hline Promyk & 11,3 & 9,5 & 5,7 & $10,0 \mathrm{c}$ \\
\hline New Yorker & 11,0 & 9,3 & 6,2 & $8,9 \mathrm{~b}$ \\
\hline Average & $8,9 \mathrm{c}$ & 7,9 & $5,5 \mathrm{a}$ & \\
\hline
\end{tabular}

Table 2

Number of leaves of seedlings grown from seeds germinating after 5. 7, and 10 days (each/plan). mean values from the period 1992-1994.

\begin{tabular}{|l|c|c|c|c|}
\hline \multirow{2}{*}{ Cultivar } & \multicolumn{4}{|c|}{ Number of days from seed sowing to germination } \\
\cline { 2 - 5 } & $\mathbf{5}$ & $\mathbf{7}$ & $\mathbf{1 0}$ & Average \\
\hline Beta & 3,1 & 2,7 & 2,0 & $6,3 \mathrm{a}$ \\
\hline Betalux & 2,6 & 2,6 & 1,8 & $6,1 \mathrm{a}$ \\
\hline Promyk & 3,6 & 2,8 & 1,3 & $10,0 \mathrm{c}$ \\
\hline New Yorker & 3,0 & 2,3 & 1,7 & $8,9 \mathrm{~b}$ \\
\hline Average & $3,1 \mathrm{c}$ & $2,6 \mathrm{~b}$ & $1,8 \mathrm{a}$ & \\
\hline
\end{tabular}


Table 3

Diameter of root collar in seedlings grown from seeds germinating after 5. 7, and 10 days (in mm), mean values from the period 1992-1994.

\begin{tabular}{|l|c|c|c|c|}
\hline \multirow{2}{*}{ Cultivar } & \multicolumn{4}{|c|}{ Number of days from seed sowing to germination } \\
\cline { 2 - 5 } & $\mathbf{5}$ & $\mathbf{7}$ & $\mathbf{1 0}$ & Average \\
\hline Beta & 2,1 & 2,1 & 1,7 & $2,0 \mathrm{~b}$ \\
\hline Betalux & 2,1 & 2,3 & 1,5 & $2,0 \mathrm{~b}$ \\
\hline Promyk & 2,4 & 2,0 & 1,3 & $2,1 \mathrm{c}$ \\
\hline New Yorker & 2,3 & 2,0 & 1,4 & $1,9 \mathrm{a}$ \\
\hline Average & $2,2 \mathrm{c}$ & $2,1 \mathrm{~b}$ & $1,5 \mathrm{a}$ & \\
\hline
\end{tabular}

Table 4

Weight of seedlings grown from seeds germinating after 5, 7, and 10 days (in g/plant), mean values from the period 1992-1994.

\begin{tabular}{|l|c|c|c|c|}
\hline \multirow{2}{*}{ Cultivar } & \multicolumn{4}{|c|}{ Number of days from seed sowing to germination } \\
\cline { 2 - 5 } & $\mathbf{5}$ & $\mathbf{7}$ & $\mathbf{1 0}$ & Average \\
\hline Beta & 0,76 & 0,54 & 0,38 & $0,59 \mathrm{a}$ \\
\hline Betalux & 0,81 & 0,63 & 0,33 & $0,62 \mathrm{a}$ \\
\hline Promyk & 1,00 & 0,70 & 0,25 & $0,76 \mathrm{~b}$ \\
\hline New Yorker & 1,20 & 0,70 & 0,36 & $0,78 \mathrm{~b}$ \\
\hline Average & $0,95 \mathrm{c}$ & $0,64 \mathrm{~b}$ & $0,34 \mathrm{a}$ & \\
\hline
\end{tabular}

\section{DISCUSSION}

Seed germination energy and germination capacity determined on the first and last count date according to the Polish standard are traditional determinants of seed quality (Grzesiuk, 1967; Grzesiuk, Kulka, 1981; Lityński, 1982). It was shown that these determinants are of very high practical value as the seeds with high level of germination capacity are less susceptible to the harmful influence of the environment (Dorywalski et al., 1956; Bradford, 1986), and the seeds with low germination capacity do not guarantee good emergence even if the sowing rate was increased (Woyke et al., 1990; Tendaj, Gruszecki, 1995a; Tendaj, Gruszecki, 1995b). However, numerous authors (Kot ow ski, 1927 Perry, 1981; Lit yński, 1982; Woyke et al., 1990) point to discrepancies between laboratory evaluation of 
seeds, where the conditions of germination are optimum, and emergencies in field conditions that are to different extends worse due to more or less unfavourable environmental conditions.

In the case of plants grown from seedlings such as tomato, the equivalent of field germination is seed germination during production of seedlings in the greenhouse or seedbed where the conditions of growth are not always as good as in laboratory.

The experiments presented in this paper covered two parallel tests of seed evaluation: in the laboratory conditions in thermostat, and in the greenhouse. Numerous author (Kotowski, 1927; Bierhuizen, Wagenvoort, 1974; Thompson, 1974, Mobayen, 1980; Coons et al., 1989) dermined ranges of minimum, optimum, and maximum temperature for the germination of tomato seeds. In the present experiment the temperature applied in the laboratory conditions was adjusted to the requirements of the Polish standard, whereas greenhouse temperature was $20-28{ }^{\circ} \mathrm{C}$ during the day in agreement with the conditions stated in literature (Kotowski, 1927; Mobayen, 1980; Coons et al., 1989) and $14-20{ }^{\circ} \mathrm{C}$ at night give lower than the optimum.

Seeds of the studied tomato cultivars germinated quicker in the thermostat than in the greenhouse conditions. It can be concluded that the higher seed germination rate in the thermostat resulted from more favourable temperature level as compared to the greenhouse conditions. Poorer germination in 1994 was probably the result by the generally worse seed quality (the seeds used for the present experiment were bought in the specialist shops).

In earlier work on tomato seed germination presented by Dąbrows k a (1992) the seeds of cv. Beta showed a lower germination capacity as compared these of cv. New Yorker (61,6\% and 67,5\% respectively), but higher, even though at a rather low level, germination energy ( $44,7 \%$ and $36,4 \%$ respectively).

In the present study, the seeds of the above mentioned cultivars germinating in the thermostat were characterized by a considerably higher germination energy $(92,0 \%)$ and germination capacity $(96 \%)$ than the seeds of Beta cultivar (respectively, $77 \%$ and $86 \%$ ).

Similar relations occurred also during seed germination in the greenhouse even though in these conditions the seeds were characterized by lower values of the studied parameters (Beta - germination energy of $41,0 \%$, germination capacity $-75 \%$, New Yorker $-61 \%$ and $95 \%$, respectively).

The studies carried out confirmed earlier results showing poorer energy and capacity of germination in Beta and Betalux cultivars when compared to New Yorker. These two cultivars were especially susceptible to temperature and it was very important to secure optimum temperature at germination for them, i.e. $26-28{ }^{\circ} \mathrm{C}$. Studies proved that in variable temperature ranging from 20 to $28{ }^{\circ} \mathrm{C}$ during the day and $14-20{ }^{\circ} \mathrm{C}$ at night the seeds of these cultivars had considerably lower (2-3 times) energy of germination. Securing optimum temperature at germination increases also the final number of germinated seeds. The seeds of the Promyk cultivar are not as susceptible to germination temperature as the seeds of Beta type - they germinate better in the wider range of temperatures. 
In the available literature on the subject no data was found on the influence of the germination rate on quality of seedlings obtained. Some stressed only that the meaning of germination energy and germination capacity of a given batch of seed (Pinchinat, Woyke, 1990).

\section{CONCLUSIONS}

1. Cultivars Beta and Betalux were characterized by considerably lower energy and germination capacity when compared with the seeds of cvs. Promyk and New Yorker.

2. Seeds of cvs. Beta and Betalux were especially sensitive to temperature and it was vital to ensure for their germination optimum temperature $\left(26-28{ }^{\circ} \mathrm{C}\right)$.

3 . Seed germination rate influenced the quality of seedlings. The seedlings grown from seeds that germinated after 5 days were significantly higher than those that germinated after 7 or 10 days. They also had higher number of leaves, larger diameter of root collar and higher fresh mass.

\section{References}

Bierhuizen J. F., Wagenvoort W. A.. 1974. Some aspects of seed germination in vegetables. I. The determination and application of heat sums and minimum temperature for germination. Si. Hortic.

2: $213-219$

Bradford K. J., 1986. Manipulation of seed water relation via osmotic priming to improve germination under stress condition. HortScience, 21 (5): 1105 - 1112

Coons J. M., Kuehl R. O., Oebker N. F., Simons N. R.. 1989. Germination of eleven tomato phenotypes at constant or alternating high temperatures. Hort. Sci., 24 (6): 927 - 930

Dąbrowska B .. 1992. Genotypowe i ekologiczne uwarunkowania wigoru nasion wczesnych form pomidora ( Lycopersicon esculentum Hill. ) Zesz. Nauk. SGGW, Rozprawy Naukowe i Monografie: 25 - 26.

Dąbrowska B.. Pyzik T., 1988. Ocena wartości siewnej nasion pomidorów odmian Beta w porównaniu z nasionami odmiany New Yorker jako standardem. Rocz. AR w Poznaniu, CXCIV: $16-25$

Dorywalski J., Goryński A., Rożnowska L., Tucholska H., Woyciechowicz M., 1956. Nasiennictwo roślin warzywnych. PWRiL. Warszawa

Grzesiuk S.. 1967. Fizjologia nasion. PWRiL, Warszawa

Grzesiuk S.. Kulka H. 1981. Fizjologia i biochemia nasion. PWRiL, Warszawa

Kotowski F., 1927. Wpływ temperatury na kiełkowanie i wzrost roślin. Rocz. Nauk Roln. i Leśn. XVII. 3: $397-405$

Lityński M., 1982. Biologiczne podstawy nasiennictwa. PWN, Warszawa

Mobayen R. G.. 1980. Germination and emergence of citrus and tomato seeds in relation to temperature. J. Hort. Sci., 55 (3): $291-297$

Perry D. A., 1981. Handbook of Vigour Test Methods. ISTA, Zurich, Szwajcaria

Pinchinat B., Woyke H., 1990. Zależność między zdolnością kiełkowania nasion a wschodami warzyw w polu. Cz. X. Pomidor. Biul. Warz., XXXV, $109-117$

Polska Norma, 1979. Materiał siewny. Metody badania nasion PN-79/R-65950

Tendaj M., Gruszecki R., 1995a. Wpływ jakości nasion na plonowanie cebuli uprawianej na dymkę. „Nowe technologie a jakość plonu warzyw”. Mat. konf., Wrocław: $35-38$

Tendaj M., Gruszecki R., 1995b. Wpływ zdolności kiełkowania nasion na wschody i liczbę cebul dymki. „Fizjologiczne Aspekty Produkcji Ogrodniczej”. Mat. konf., Kraków: 64 - 67

Woyke H., Sokołowska A., Szafirowska A., 1990. Zależność między zdolnością kiełkowania a wschodami warzyw w polu. Cz. I. Ogólna - synteza. Biul. Warz. XXXV:1 - 30 


\section{Wpływ dynamiki kiełkowania nasion na zróżnicowanie morfologiczne siewek pomidora}

\section{Streszczenie}

Celem przeprowadzonych badań było określenie zależności między jakością kiełkowania nasion a zróżnicowaniem morfologicznym siewek badanych odmian pomidora. Ocenie poddano nasiona 3 bardzo wczesnych odmian pomidora (Beta, Betalux, Promyk) w porównaniu ze średnio wczesną odmianą New Yorker, traktowaną jako wzorzec. Wykazano, że tempo kiełkowania nasion miało istotny wpływ na jakość uzyskanych $\mathrm{z}$ nich siewek. Siewki wyrosłe z nasion kiełkujących po 5 dniach były istotnie wyższe od siewek wyrosłych z nasion kiełkujących po 7 i 10 dniach, charakteryzowały się istotnie większą liczbą liści, średnicą szyjki korzeniowej i masą roślin. 